Нефтегазовое дело. 2021. Т. 19, № 5. С. 149-156. ISSN 2073-0128 (print)

Petroleum Engineering. 2021. Vol. 19, No. 5, P. 149-156. ISSN 2073-0128 (print)

Original article

UDC 622.23 .05

doi: 10.17122/ngdelo-2021-5-149-156

\title{
STUDY OF THE EFFECT OF ELECTROHYDRAULIC DISCHARGE ON ROCK WASTE IN LIQUID MEDIUM
}

\author{
Alexander A. Rukomoynikov ${ }^{1,2}$, Eldar R. Abdeev ${ }^{1,2}$, Yuri V. Mikhailov' \\ 'Bashkir State University, Ufa, Russia \\ ${ }^{2}$ Russian University of Chemical Technology named after D.I. Mendeleev, Moscow, Russia \\ Corresponding author \\ Alexander A. Rukomoynikov, alex@bgutmo.ru
}

\begin{abstract}
There is a problem of the presence of waste, which is being predominantly in a homogeneous state in the form of coal and hydrocarbon-containing environment, located in the mines. The results of studies of the effect of electrohydraulic shock on rock waste in a liquid medium are presented on the example of coal. As a result of the experiments, the optimal range of electrohydraulic discharges was determined for the effective separation of waste into hydrocarbon-containing components and sediments with the formation of a coal-water mixture with a solid particle size of no more than $3 \mathrm{~mm}$. The paper presents a structure intended for crushing rock waste in a liquid medium, a structural diagram of the arrangement of the device in the technological process. The optimal number of electrohydraulic discharges, contributing to the separation of wastes, which are being predominantly in a homogeneous state in the form of coal and a hydrocarbon-containing medium, is revealed, the amount of sediment in the coal-water mixture is determined.

The rock crushing device belongs to the mining industry and can be used for separation, grinding and transportation of mining waste such as coal. Experimental studies of electrohydraulic discharges on rocks were carried out on a model device, the purpose of which was to study the effect of electrohydraulic discharge on rock waste in a liquid medium. The experiments were carried out in the laboratory of experimental research at the Faculty of Engineering of the Bashkir State University.
\end{abstract}

Keyword

electrohydraulic discharge, mining industry, rock crushing device, model device, rock waste, hydrocarbon medium

\section{For citation:}

Rukomoynikov A.A., Abdeev E.R., Mikhailov Yu.V. Study of the Effect of Electrohydraulic Discharge on Rock Waste in Liquid Medium // Нефтегазовое дело. 2021. Т. 19, № 5. С. 149-156. https://doi.org/10.17122/ngdelo-2021-5-149-156.

Научная статья

\section{ИССЛЕДОВАНИЕ ВОЗДЕЙСТВИЯ ЭЛЕКТРОГИДРАВЛИЧЕСКОГО УДАРА НА ОТХОДЫ ГОРНЫХ ПОРОД В ЖИДКОЙ СРЕДЕ}

\section{Александр Александрович Рукомойников ${ }^{1,2}$, Эльдар Ринатович Абдеев ${ }^{1,2}$, Юрий Владимирович Михайлов'}

'Башкирский государственный университет, Уфа, Россия

Российский химико-технологический университет им. Д.И. Менделеева, Москва, Россия

Автор, ответственный за переписку:

Александр Александрович Рукомойников, alex@bgutmo.ru

(C) Rukomoynikov A.A., Abdeev E.R., Mikhailov Yu.V., 2021 
Аннотация. Существует проблема наличия отходов, пребывающих преимущественно в однородном состоянии в виде каменного угля и углеводородсодержащей среды, находящихся в отработанных шахтах. Представлены результаты исследований воздействия электрогидравлического удара на отходы горных пород в жидкой среде на примере каменного угля. В результате экспериментов установлен оптимальный диапазон электрогидравлических ударов для эффективного разделения отходов на углеводородсодержащие компоненты и осадки с формированием водоугольной смеси с размерами твердых частиц не более 3 мм. В работе представлена конструкция, предназначенная для измельчения отходов горных пород в жидкой среде, предложена структурная схема расположения устройства в технологическом процессе. Выявлено оптимальное количество воздействий электрогидроразрядов, способствующих разделению отходов, пребывающих преимущественно в однородном состоянии в виде каменного угля и углеводородсодержащей среды, определено количество осадка в водоугольной смеси.

Устройство для измельчения горных пород относится к горнодобывающей промышленности и может быть использовано для разделения, измельчения и транспортировки отходов добычи полезных ископаемых, таких как каменный уголь.

На модельном устройстве проведены экспериментальные исследования электрогидроразрядов на горные породы, целью которых являлось исследование воздействия электрогидравлического удара на отходы горных пород в жидкой среде. Опыты проводились в лаборатории экспериментальных исследований на инженерном факультете Башкирского государственного университета.

\section{Ключевые слова}

электрогидроразряд, горнодобывающая

промышленность, устройство для измельчения горных пород, модельное устройство, отходы горных пород, углеводородсодержащая среда

\section{Для цитирования}

Rukomoynikov A.A., Abdeev E.R., Mikhailov Yu.V. Study of the Effect of Electrohydraulic Shock Wave on Rock Waste in Liquid Medium. Neftegazovoe delo - Petroleum Engineering, 2021, Vol. 19, No. 5, pp. 149-156 https://doi.org/10.17122/ ngdelo-2021-5-149-156.

\section{Background}

Coal is currently one of the main sources of primary energy. Mining from mines is the most efficient way to extract coal. To simplify work at great depths, the mechanism of electrohydraulic discharge (EHD) on the formation is used [1-3].

The EHD mechanism is that hydraulic pressure impulses arising from an electric discharge directly at the bottomhole propagate through the formation and have a dispersing and deformation effect on the solid phase particles that clog the pore channels, promote their washout and removal to the bottomhole by the flow of formation fluid.

Such an impact with simultaneous drainage of fluid from the formation increases the productivity of the well by $1.5-2$ times $[4,5]$.

The purpose of this work is to study the effect of electrohydraulic discharge on rock waste in a liquid medium by conducting experiments on a model device for efficient separation of waste into hydrocarbon-containing components and sediments with the formation of a coal-water mixture and their transportation.

\section{Design of the device}

The rock crushing device belongs to the mining industry and can be used to separate, grind and transport mining waste such as coal [6].

A rock crushing device is shown in Figure 1. Power supply of the tool with an electric current is carried out with an alternating current of a frequency of 300-1000 Hz, and the control of the downhole tool is carried out by a pulsed action of a direct current from the ground block of equipment. The layout of the device for crushing and transporting rocks in the technological process is shown in Figure 2, where 6 is a high-impulse installation; 7 - water supply pump; 8 - device for crushing and transporting rocks; 9 - suction pump; 10 - sump tank. The technical result of the proposed device is the crushing of rocks to a size equal or less than the size of the mesh cell, convenient for transportation and further treatment [7].

The EHD installation for is shown in Figure 4. Figure 3 shows the Test capacity for the implementation of EHD, in which a grating with $\mathrm{d}=1 \mathrm{~mm}$ or $\mathrm{d}=3 \mathrm{~mm}$ is placed. Figure 5 shows the electrical diagram for the device. 


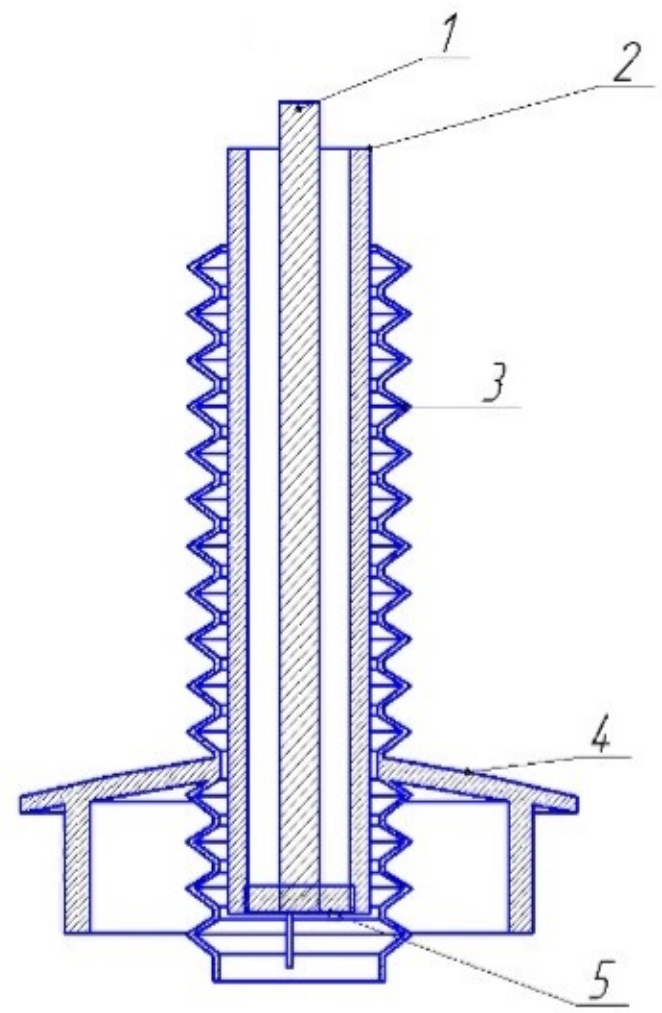

1 - electrode; 2 - pipe; 3 - protective corrugated tube; 4 - rubber rim; 5 - mesh

Figure 1. Rock crushing and transporting device

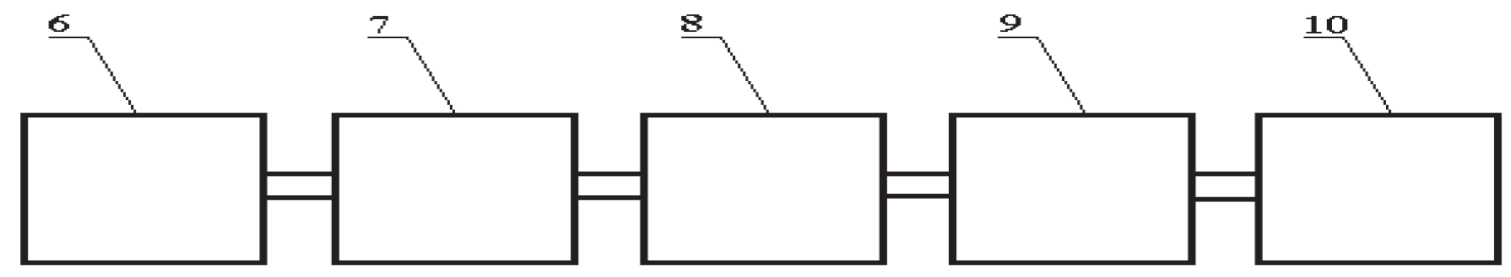

Figure 2. Layout of the rock crushing and transporting device in the technological process

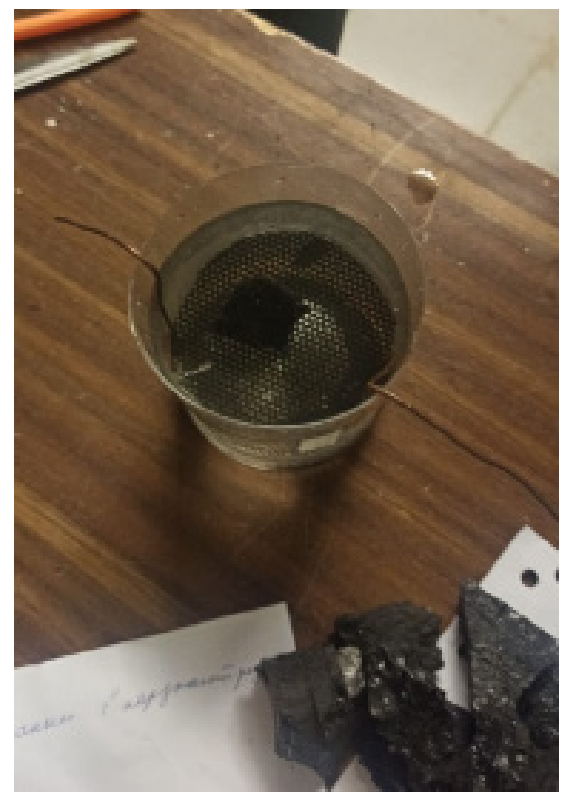

Figure 3. Test capacity with grid

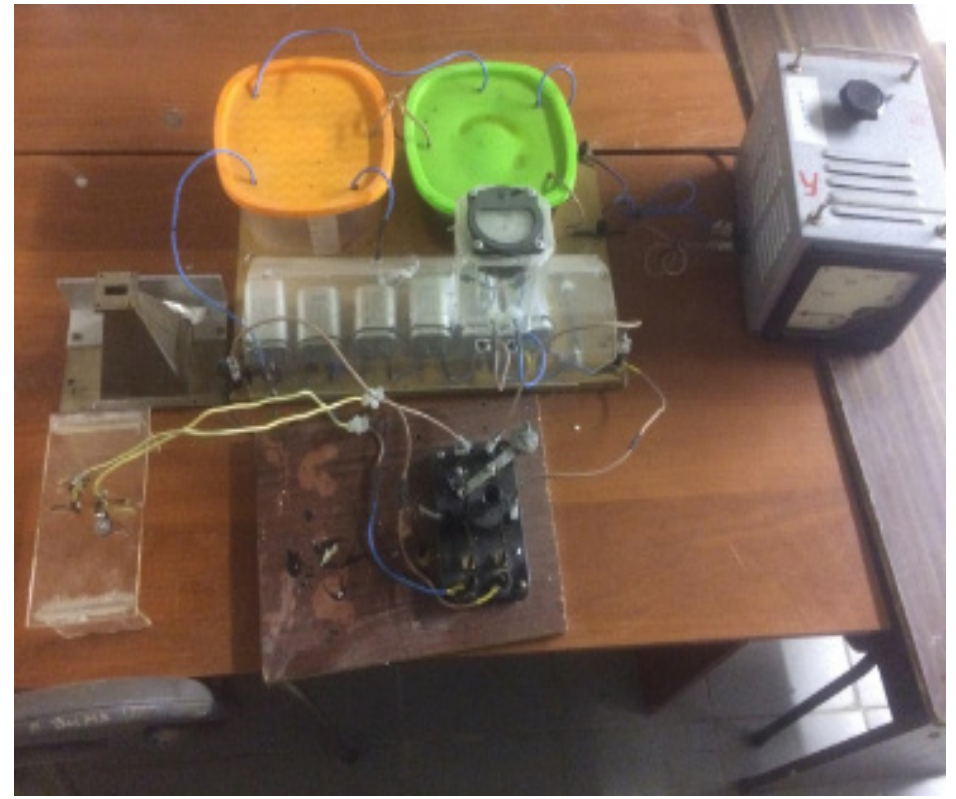

Figure 4. EHD installation 


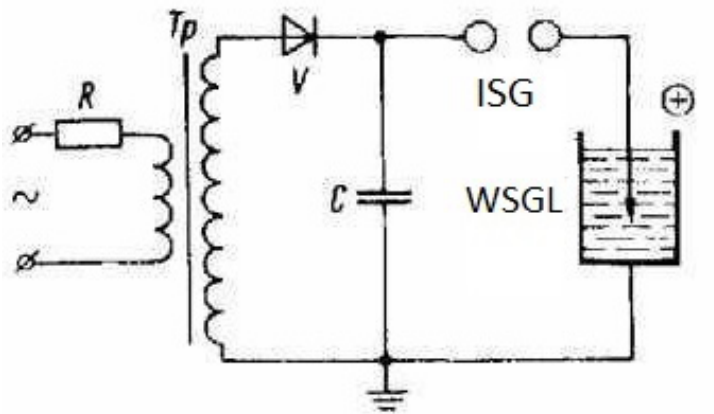

$\mathrm{R}$ - charging resistance, $\mathrm{Tp}$ - transformer; V - rectifier; ISG — intermedi+ate spark gap; WSGL - working and spark gap in the liquid; $\mathrm{C}$ - capacitor

Figure 5. Electrical scheme for reproducing electrohydraulic discharge

\section{Experimental part}

The purpose of experimental study of EHD on rocks is to study the effect of electrohydraulic shock on rock waste in a liquid medium by conducting experiments on a model device for efficient separation of waste into hydrocarbon-con- taining components and sediments with the formation of a coal-water mixture, and their transportation.

The water is exposed to pulses of high voltage electrical discharge at a voltage of about $15-20 \mathrm{kV}$. The experiment was carried out in the laboratory of experimental research at the Faculty of Engineering, BashSU, in 001a laboratory. The duration of one experiment is $2 \mathrm{~min}$ at a voltage of $15000 \mathrm{~V}$. Below there is a description of the course of the experiment:

1. Measurement of the mass of the original product;

2. Placing the product in a working tank/ capacity;

3. Setting of operating voltage at $15000 \mathrm{~V}$;

4. Hydro-pulse discharge;

5. Measurement of product mass after hydropulse discharge;

6. Repeated treatment by hydro-pulse discharge;

7. Examination of the sediment with the use of a microscope.

Table 1. Experimental data

\begin{tabular}{|c|c|c|c|c|c|}
\hline \multicolumn{5}{|c|}{ Voltage 15000 V } \\
\hline \multicolumn{2}{|c|}{ Mesh d=1 mm } & \multicolumn{3}{c|}{ Mesh d=3 mm } \\
\hline $\begin{array}{c}\text { Mass before } \\
\text { exposure, } \mathrm{g}\end{array}$ & $\begin{array}{c}\text { Mass after } \\
\text { exposure, } \mathrm{g}\end{array}$ & $\begin{array}{c}\text { Number of strokes } \\
\text { (shock waves) }\end{array}$ & $\begin{array}{c}\text { Mass before } \\
\text { exposure, } \mathrm{g}\end{array}$ & $\begin{array}{c}\text { Mass after } \\
\text { exposure, } \mathrm{g}\end{array}$ & $\begin{array}{c}\text { Number of strokes } \\
\text { (shock waves) }\end{array}$ \\
\hline 6 & 6 & 279 & 11 & 9 & 283 \\
\hline 13 & 12 & 263 & 14 & 13 & 269 \\
\hline 14 & 10 & 254 & 17 & 14 & 258 \\
\hline 17 & 16 & 251 & 16 & 15 & 256 \\
\hline 18 & 17 & 245 & 16 & 16 & 237 \\
\hline
\end{tabular}

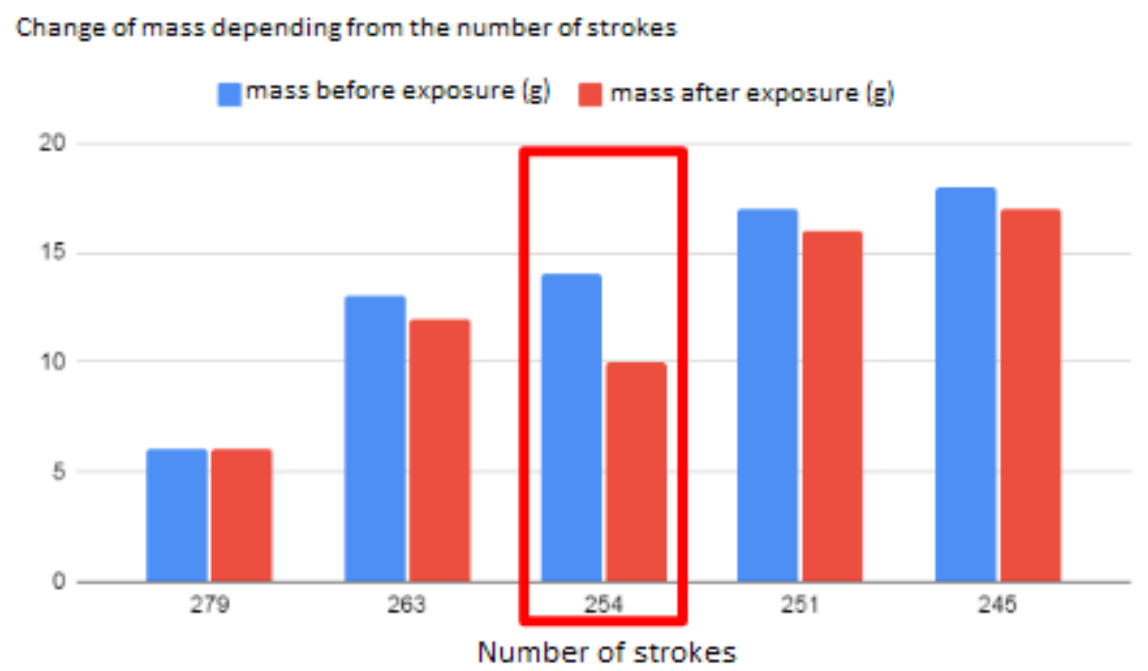

Figure 6. Numerical ratio of coal mass before and after electrohydraulic discharge. Mesh diameter $\mathrm{d}=1 \mathrm{~mm}$ 


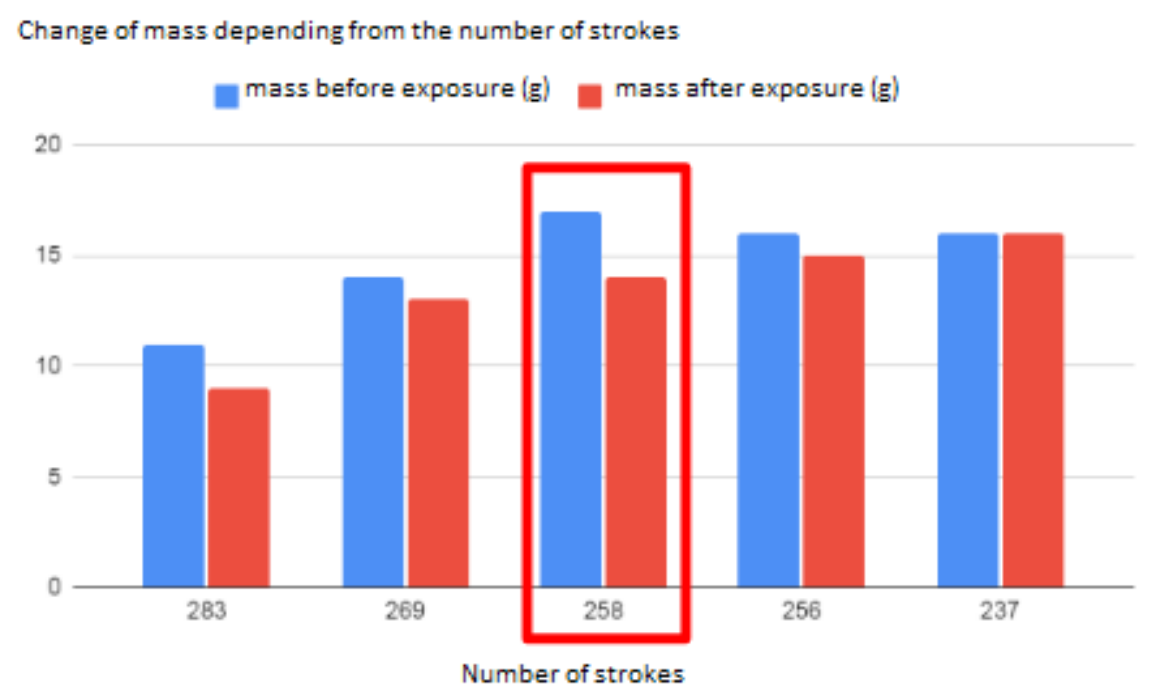

Figure 7. Numerical ratio of coal mass before and after electrohydraulic discharge. Mesh diameter $\mathrm{d}=3 \mathrm{~mm}$

\section{Trend lines}

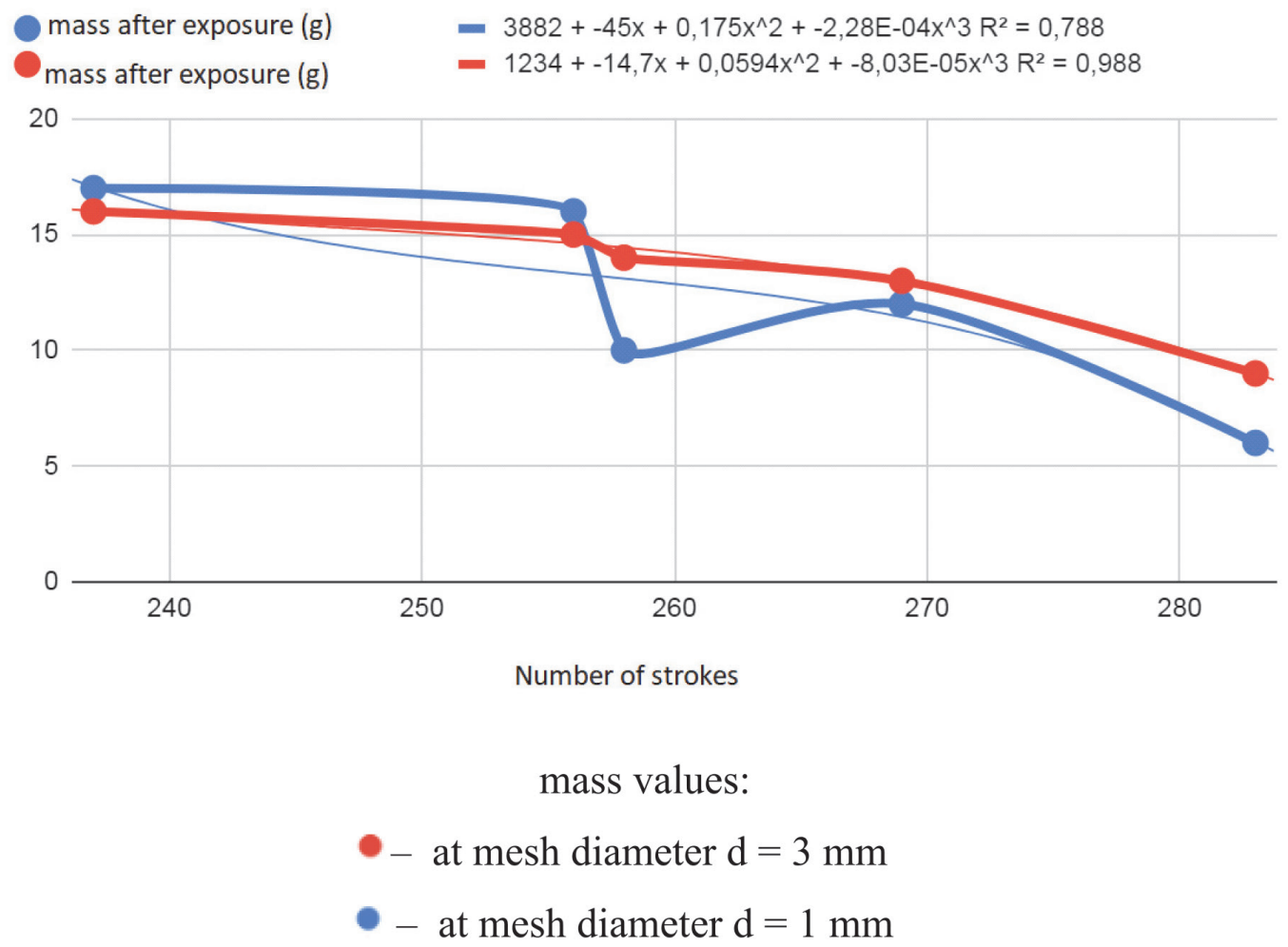

Figure 8. Trends of the ratio of the sediment mass of the coal-water mixture and the number of strokes

When constructing trend lines, a polynomial line of the 3rd degree was used.

Thus, the optimal EHD of 250 to 270 strokes/ shock waves range was identified. When operating within the specified range, the sediment size is less than $3 \mathrm{~mm}$.

Safety regulations and process automation

Dielectric mats must be spread in front of the control panel of the electrohydraulic installation, as well as in all passages between the blocks of the electrohydraulic installation.

In electrohydraulic installations, complex circuits of the discharge circuits of installations with auxiliary devices are used that provide an electrical breakdown of one or more gaps in the technological unit [8].

Reliably grounded solid metal housings and frames of blocks and elements of technological 
equipment of electrohydraulic installations can serve as protective screens.

For installations of medium and high power, special capacitors, rectifiers, arresters and electrodes are required. Capacitors used in electrohydraulic installations should have a low self-inductance and must operate in a pulsed mode for a long time [9].

The main way, which is most widely used in development practice by means of automation of the experiment, is the way of providing registration and data collection in combination with the operational control of the experiment using a computer through the appropriate communication units, substantially bypassing the control system of the machine itself, which is used only in the case of an autonomous experiment. In this case, the autonomous control system of the electrohydraulic installation is supplemented by a control computer and the test complex under consideration has the ability to operate in two modes: both autonomous and controlled from a computer [10].

In this work, the choice of the optimal interelectrode spacing in the working chamber was carried out experimentally by studying the current oscillograms. The previously cited criteria for the optimality of the interelectrode distance: electrohydraulic installations are not entirely accurate as applied to grouting slurries, since the latter are subject to a complex set of requirements based on the geological and technical conditions of cemented wells. In this case, the quality of the solu-

\section{REFERENCES}

1. Isakov Yu.V., Dubrovskiy V.A., Potylitsyn M.Yu., Potapov I.I., Shirokov V.N. Research of Efficiency of Obtaining Water-Coal Fuel by the Electrohydraulic Method. Power Plants 2012. — Serbia: Society of Thermal Engineers of Serbia. 2012. Available at: http://e2012.drustvo-termicara. com/english/list-ofsubmitted-papers/4 (accessed 15.08.2021).

2. Kusaiynov K., Nusupbekov B.R., Shaimerdenova K.M., Bulkairova G.A., Khasenov A.K. Ispol'zovanie eletrogidroimpul'snogo metoda dlya pererabotki prirodnykh mineralov i tekhnogennogo syr'ya [The Use of the Electrohydropulse Method for the Processing of Natural Minerals and Technogenic Raw Materials]. Materialy mezhdunarodnogo soveshchaniya «Progressivnye metody obogashcheniya i kompleksnoi pererabotki prirodnogo $i$ tekhnogennogo mineral'nogo syr'ya. Plaksinskie chteniya 2014» [Materials of the International Meeting «Progressive Methods of Enrichment and Complex Processing of Natural and Technogenic Mineral Raw Materials. Plaksin Readings 2014»]. Almaty, Institut metallurgii i obogashcheniya Publ., 2014, pp. 129-132. [in Russian].

3. Rukomoinikov A.A., Abdeev E.R., Abdeev R.G. Ugol'nyi reaktor, primenenie elektrogidravlicheskogo effekta v ugol'noi promyshlennosti [A Coal Reactor, the Use tion is assessed by a number of indicators, one of which must be improved, and others, worsened.

Due to energy losses in the connecting wires and storage elements, in the discharge channel and in the gas cavity, only an insignificant part of the accumulated energy is supplied during the breakdown of the gap or explosion of the wire to the object of processing. However, during a discharge in a liquid, high energy concentrations and processing rates are achieved $[11,12]$, which determines the field of application of electrohydraulic installations.

\section{Conclusion}

Thus, it is determined that the optimal range of electrohydraulic discharges is from 250 to 270 strokes, which contributes to the separation of waste, being predominantly in a homogeneous state in the form of coal and a hydrocarbon-containing medium, the determination of the sediment close to the coal-water mixture. When working within the specified limits, the size of the sediments is less than $3 \mathrm{~mm}$.

The methods of upgrading the installation to increase throughflow capacity and reduce energy costs were considered, as well as the possibility of using an automatic mode, when only one commissioning engineer for production is required.

All of the above indicates the possibility of increasing the spread of this technique in production due to its effectiveness.

of Electrohydraulic Effect in Coal Industry]. Sbornik trudov mezhdunarodnoi nauchno-tekhnicheskoi konferentsii «Sovremennye tekhnologii v neftegazovom dele - 2017»: V $2 T$. [Proceedings of the International Scientific and Technical Conference «Modern Technologies in Oil and Gas Business - 2017»: In 2 Volumes]. Ufa, UGNTU Publ., 2017, pp. 188-192. [in Russian].

4. Locke B.R., Sato M., Sunka P., Hoffmann M.R., Chang J.-S. Electrohydraulic Discharge and Nonthermal Plasma for Water Treatment. Industrial and Engineering Chemistry Research, 2006, Vol. 45, Issue 3, pp. 882-905. DOI: 10.1021/ie050981u.

5. Dubrovskii V.A., Isakov Yu.V., Potylitsyn M.Yu., Potapov I.I., Shirokov V.N. Primenenie elektrogidravlicheskogo sposoba polucheniya vodougol'nogo topliva dlya kotel'nykh ustanovok [Application of an ElectroHydraulic Method for Producing Coal-Water Fuel for Boiler Plants]. Energetik - Energetik, 2011, No. 7, pp. 24-27. [in Russian]

6. Belov A.A., Musenko A.A., Vasilev A.N., Toporkov V.N. Obosnovanie ustroistva dlya elektrogidravlicheskoi obrabotki vodnykh rastvorov [Justification of a Device for Electrohydraulic Treatment of Aqueous Solutions]. Vestnik agrarnoi nauki Dona - Don Agrarian Science Bulletin, 2019, No. 2 (46), pp. 23-29. [in Russian]. 
7. Semkin B.V., Usov A.F., Kurets V.I. Osnovy elektroimpul'snogo razrusheniya materialov [The Principles of Electric Impulse Destruction of Materials]. St. Petersburg, Nauka Publ., 1995. 276 p. [in Russian].

8. Yutkin L.A. Elektrogidravlicheskii effekt i ego primenenie $v$ promyshlennosti [Electro-Hydraulic Effect and its Application in Industry]. Leningrad, Mashinostroenie Publ., 1986. 252 p. [in Russian].

9. Naugolnykh K.A., Roi N.A. Elektricheskie razryady $v$ vode [Electric Discharges in Water]. Moscow, Nauka Publ., 1971. 155 p. [in Russian].

10. Belov A.A. Modelirovanie otsenki faktorov vliyaniya na protsess elektrogidravlicheskoi obrabotki vody [Modeling the Estimation of Factors of Influence on the Process Electrohydraulic Treatment of Water]. Vestnik NGIEI - Bulletin NGII, 2018, No. 11 (90), pp. 103-112. [in Russian].

11. Kurets V.I., Usov A.F., Tsukerman V.A. Elektroimpul'snaya dezintegratsiya materialov [Electric Pulse Discharge Disintegration of Materials]. Apatity, Kol'skogo nauchnogo tsentra RAN Publ., 2002. 321 p. [in Russian].

12. Rukomoinikov A.A., Saitov R.I., Abdeev R.G., Abdeev E.R., Shvetsov M.V., Talypov Sh.M., Menshaev A.N. Elektrogidravlicheskii smesitel' dlya smesheniya tekhnicheskikh zhidkostei [Electro-Hydraulic Mixer for Mixing Technical Liquids]. Patent RF, No. 189419, 2019. [in Russian].

\section{СПИСОК ИСТОЧНИКОВ}

1. Isakov Yu.V., Dubrovskiy V.A., Potylitsyn M.Yu., Potapov I.I., Shirokov V.N. Research of Efficiency of Obtaining Water-Coal Fuel by the Electrohydraulic Method // Power Plants 2012. - Serbia: Society of Thermal Engineers of Serbia. 2012. URL: http://e2012.drustvotermicara.com/english/list-ofsubmitted-papers/4 (дата обращения: 15.08.2021).

2. Кусайынов К., Нусупбеков Б.Р., Шаймерденова К.М., Булкаирова Г.А., Хасенов А.К. Использование элетрогидроимпульсного метода для переработки природных минералов и техногенного сырья // Прогрессивные методы обогащения и комплексной переработки природного и техногенного минерального сырья.
Плаксинские чтения 2014: матер. международ. совещания. Алматы: Институт металлургии и обогащения, 2014. С. 129-132.

3. Рукомойников А.А., Абдеев Э.Р., Абдеев Р.Г. Угольный реактор, применение электрогидравлического эффекта в угольной промышленности // Современные технологии в нефтегазовом деле - 2017: сб. тр. междунар. науч.-тех. конф.: В 2 Т. Уфа: Изд-во УГНТУ, 2017. C. $188-192$.

4. Locke B.R., Sato M., Sunka P., Hoffmann M.R., Chang J.-S. Electrohydraulic Discharge and Nonthermal Plasma for Water Treatment // Industrial and Engineering Chemistry Research. 2006. Vol. 45. Issue 3. P. 882-905. DOI: $10.1021 / \mathrm{ie} 050981 \mathrm{u}$.

5. Дубровский В.А., Исаков Ю.В., Потылицын М.Ю., Потапов И.И., Широков В.Н. Применение электрогидравлического способа получения водоугольного топлива для котельных установок // Энергетик. 2011. № 7. C. 24-27.

6. Белов А.А., Мусенко А.А., Васильев А.Н., Топорков В.Н. Обоснование устройства для электрогидравлической обработки водных растворов // Вестник аграрной науки Дона. 2019. № 2 (46). С. 23-29.

7. Семкин Б.В., Усов А.Ф., Курец В.И. Основы электроимпульсного разрушения материалов. СПб.: Наука, 1995. $276 \mathrm{c}$.

8. Юткин Л.А. Электрогидравлический эффект и его применение в промышленности. Л.: Машиностроение, 1986. $252 \mathrm{c}$

9. Наугольных К.А., Рой Н.А. Электрические разряды в воде. М.: Наука, 1971. 155 с.

10. Белов А.А. Моделирование оценки факторов влияния на процесс электрогидравлической обработки воды // Вестник НГИЭИ. 2018. № 11 (90). С. 103-112.

11. Курец В.И., Усов А.Ф., Цукерман В.А. Электроимпульсная дезинтеграция материалов. Апатиты: Кольского научного центра РАН, 2002. 321 с.

12. Пат. 189419 РФ, МПК В 01 F 13/00. Электрогидравлический смеситель для смешения технических жидкостей / А.А. Рукомойников, Р.И. Саитов, Р.Г. Абдеев, Э.Р. Абдеев, М.В. Швецов, Ш.М. Талыпов, А.Н. Меньшаев. 2018138410, Заявлено 30.10.2018; Опубл. 22.05.2019.

\section{INFORMATION ABOUT THE AUTHORS ИНФОРМАЦИЯ ОБ АВТОРАХ}

Alexander A. Rukomoynikov, Post-graduate Student, Assistant of Technological Machines and Equipment Department, Chairman of the Council of Young Scientists of the Bashkir State University from Faculty of Engineering, Bashkir State University, Ufa, Russia; Under-graduate Student of of Logistics and Economic Informatics Department, Russian University of Chemical Technology named after D.I. Mendeleev, Moscow, Russia

Рукомойников Александр Александрович, аспирант, ассистент кафедры «Технологические машины и оборудование», председатель Совета молодых ученых БашГУ от инженерного факультета, Бамкирский государственный университет, Уфа, Россия; магистрант кафедры логистики и экономической информатики, Российский химико-технологический университет им. Д.И. Менделеева, Москва, Россия

alex@bgutmo.ru 
Eldar R. Abdeev, Candidate of Engineering Sciences, Assistant Professor of Technological Machines and Equipment Department, Faculty of Engineering, Bashkir State University, Ufa, Russia; Under-graduate Student of Logistics and Economic Informatics Department, Russian University of Chemical Technology named after D.I. Mendeleev, Moscow, Russia

Абдеев Эльдар Ринатович, кандидат технических наук, доцент кафедры «Технологические машины и оборудование» Инженерного факультета, Башкирский государственный университет, Уфа, Россия; магистрант кафедры логистики и экономической информатики, Российский химико-технологический университет им. Д.И. Менделеева, Москва, Россия

air@bgutmo.ru

Yuri V. Mikhailov, Post-graduate Student of Technological Machines and Equipment Department, Faculty of Engineering, Bashkir State University, Ufa, Russia

Михайлов Юрий Владимирович, аспирант кафедры «Технологические машины и оборудование» Инженерного факультета, Башкирский государственный университет, Уфа, Россия

m@bgutmo.ru

The article was submitted 19.04.2021; approved after reviewing 17.08.2021; accepted for publication 03.09.2021.

Статья поступила в редакиию 19.04.2021; одобрена после рецензирования 17.08.2021; принята к публикаџии 03.09.2021. 